\title{
Restorative Justice Approach to Alternatives to Detention: An Analysis of Canadian Immigration Detention
}

\author{
By: Maia Fujimoto \\ BA, Hons. Peace and Conflict Studies, University of Waterloo, 2016
}

\begin{abstract}
A Major Research Paper presented to Ryerson University in partial fulfillment of the requirements for the degree of Master of Arts in the Program of Immigration and Settlement Studies
\end{abstract}

Toronto, Ontario, Canada, 2018

(C) Maia Fujimoto 2018 


\section{AUTHOR'S DECLARATION FOR ELECTRONIC SUBMISSION OF A MAJOR RESEARCH PAPER (MRP)}

I hereby declare that I am the sole author of this MRP. This is a true copy of the MRP, including any required final revisions. I authorize Ryerson University to lend this MRP to other institutions or individuals for the purpose of scholarly research I further authorize Ryerson University to reproduce this MRP by photocopying or by other means, in total or in part, at the request of other institutions or individuals for the purpose of scholarly research. I understand that my MRP may be made electronically available to the public.

Maia Fujimoto 


\title{
Restorative Justice Approach to Alternatives to Detention: An Analysis of Canadian Immigration Detention
}

\author{
Maia Fujimoto \\ Masters of Arts, 2018 \\ Immigration and Settlement Studies \\ Ryerson University
}

\begin{abstract}
This paper presents a literature review on restorative justice, immigration detention and alternatives to detention. I propose that a restorative justice approach and practices could be taken into consideration when developing ATD programs in Canada as well as for addressing current issues that surround immigration detention. Restorative justice is a process to involve, to the extent possible, those who have a stake in a specific offence and to identify and address harms, needs and obligations collectively, with the objective to 'heal' and put things as right as possible (Zehr, 2015). There is a research gap in the field of restorative justice and immigration in general. Restorative justice traditionally aligns itself with the criminal justice system but has potential to be applied to many areas and its application to immigration issues is a relatively new area. As these concepts can provide for a new approach towards reconciling issues involving victims and offenders outside of criminal justice, an argument can be made that there is potential for the implementation of restorative justice to have value within immigration detention.
\end{abstract}

Key Words: Restorative Justice, Alternatives to Detention, Immigration detention, Canada 


\section{Acknowledgements}

I would like to thank my MRP supervisor Dr. Idil Atak for all the guidance and support that she has given me over the course of writing my MRP. This was a difficult challenge for myself, and she helped me by providing the best possible guidance and direction to explore this topic. I would also like to thank my friends and family for the consistent encouragement and support during the entire duration of my graduate studies. Thank you for believing in me when I didn't believe in myself. Lastly, I would like to especially thank my parents; Dad, for always being the voice in my head to push me further and, Mom, for always reminding me how far I've come. 


\section{Table of Contents}

Author's Declaration $\quad$ ii

Abstract iii

Acknowledgements $\quad$ iv

Introduction 1

The Scope of the Study and Methodology 4

Background Information $\quad 6$

Literature review 12

Issues surrounding Immigrant Detention as presented by literature 13

Canadian Immigration Detention Policies and Framework 22

Alternatives to Detention $\quad 24$

Restorative Justice $\quad 30$

Current Literature and Restorative Justice Programs in

Canada and around the World: Themes and Critical Issues 37

Critical Application of Restorative Justice 44

Areas for Further Research and Development 49

Conclusion $\quad 53$

Bibliography $\quad 56$

$\begin{array}{ll}\text { Glossary } & 60\end{array}$ 


\section{Introduction}

Immigration detention is increasingly becoming a more relevant and important topic in the realm of migration and human rights. This is a result of increasing problems surrounding immigration detention such as the lack of access to services for detainees, impact on individual mental health, children being put into detention and the criminalization of a group of individuals who are not criminals. Not only is immigration detention posing significant issues for the migrants themselves, but it also negatively impacts the Nation State. Immigration detention is expensive to operate and maintain (IDC, 2016). In addition, there is a backlog of migrants coming through the immigration detention system causing longer processing times and strain on administrative bodies such as the Canada Border Service Agency (CBSA), the Immigration and Refugee Board (IRB) and Immigration, Refugee and Citizenship Canada (IRCC). According to the CBSA website, between 2017-2018 there were 362 individuals who were detained over 99 days, and approximately $30 \%$ of all detainees were in provincial prisons rather than immigration holding centres (CBSA, 2018). These problems have resulted in the creation of a New Immigration Detention Framework (NIDF) in 2017 that was designed and created by the CBSA to address these issues and concerns. Within this framework, CBSA implemented, as of June 22, 2018 Alternatives to Detention (ATD) programs such as the Community Case Management and Supervision program, Voice Reporting program and an Electronic Monitoring program (CBSA, 2018) as a means of relieving the administrative pressure of detaining migrants and provide a risk-based, nationally consistent programming. Although this is a positive step regarding immigration detention in Canada, it is long overdue and might not adequately address some of the social issues, such as the access to health care, child detention and indefinite detention. The 
ATD initiative in Canada is still in the development stage, and the Canadian government needs to look to new efforts on developing its ATD programs further.

In this study, I propose that a restorative justice approach and practices could be taken into consideration when developing ATD programs in Canada as well as addressing current issues that surround immigration detention. Restorative justice is a process to involve, to the extent possible, those who have a stake in a specific offence and to identify and address harms, needs and obligations collectively, with the objective to 'heal' and put things as right as possible. (Zehr, 2015). However, I argue that there is a research gap in the field of restorative justice and immigration in general. The area of restorative justice in the field of immigration has not been researched widely by academics. Restorative justice traditionally aligns itself with the criminal justice system but could be applied to a wide range of issues and its application to immigration issues is a relatively new area. However, an argument can be made that there is potential for the implementation of restorative justice to have value within immigration detention. This is because both the immigration detention and criminal justice process share similarities regarding the approach to seeking justice. In the same way, as there are 'victims' and 'offenders' in criminal justice, there are clearly those who suffer from and are harmed by immigration detention, meaning that the victim/offender characterization could also apply. This is not to say that migrants should be considered offenders to the state, but rather that, in any conflict, there are two perspectives. The intent is not to further criminalize migrants but to highlight the perspective that there are two parties involved (victim and offender) who require that certain needs are met in order to move towards reconciliation. Research surrounding the topic of restorative justice and immigration can be significant for advancing the knowledge base in immigration detention 
especially in areas of ATD and its related issues, such as cost-effectiveness and the execution of a national detention framework that respects human rights.

Some of the questions that I explore throughout this study include: Why should the federal government look towards restorative justice for creative solutions? How can we fill the knowledge gap regarding the value of applying restorative justice principles to immigration detention and, in particular, how restorative justice might minimize the negative consequences of immigration detention? This exploration of the application of restorative justice can be significant for advancing research on areas of immigration and settlement work, especially in the Canadian context. Canada is a leader in terms of progressive outreach of active immigration and adopting a restorative justice approach can help reinforce Canada's leadership position. This study will use Canadian detention centres as a case study to examine if restorative justice could be applied to help address the various social issues that surround immigration detention and further develop ATD programs. The approach of using restorative justice for resolving interpersonal and group conflict has been successful in many cases involving victim and offenders in the Canadian criminal justice system (Harris, 2017), and has the potential to have similar results in other areas, such as immigration. In Canada, the federal government is currently working to 'transform' its immigration detention centres, and end the indefinite detention of immigrants and their children (Harris, 2017) - restorative justice could help in achieving this objective.

Immigration research is an essential focus for knowledge mobilization and knowledge transfer because of the significance immigration has within public policy in Canada (Shields, 2012). Research surrounding immigration is of great interest to policymakers as it highlights demographic changes in Canada and is linked to national security and economic growth strategy 
(Shields, 2012). The purpose and significance of the present study are to address the current knowledge gap in the use of restorative justice, specifically as it relates to solving problems with immigration detention. This topic is of significance for immigration and settlement work as there is the potential to allow the settlement sector to become more involved and invested in the government of Canada's immigration system. Restorative justice could be applied to help address specific issues that surround immigration detention including, human rights violations, Canada's compliance with its international human rights and refugee law obligations, impact on migrant mental health and wellbeing as well as the overall cost of the detention institutions themselves.

Addressing the stated research problem is essential as the resulting research answer could potentially provide an attractive solution to many social problems linked to immigration detention. The incarceration of children or prolonged trauma faced within Canadian detention centres is a direct result of shortcomings within the Canadian immigration system as it is today (CCR, 2018). The proposed research is original because it explores the application of restorative justice as a possible solution. All of these problems reflect poorly on the Canadian immigration system and do not achieve the humanitarian objectives of the Canadian government and the people of Canada (IRPA. S 3, 2002).

\section{The Scope of the Study and Methodology}

This study will primarily focus on migrants who are detained in Canadian detention centres mostly in, but not limited to Ontario, as well as the relevant policy and the possible application of restorative justice to issues that surround immigration detention and application to ATD programming in Canada. One of these immigrant holding centres (IHC) is located in 
Toronto, Ontario. However, there are also some provincial prisons where migrants are often detained, such as the Central East Correctional Centre in Lindsay, Ontario.

When highlighting the scope of this study, it is essential to underline that the groups of migrants. This study is interested in are, particularly: individuals who are claiming asylum, refused asylum seekers and those who are otherwise considered to be irregular migrants or designated foreign nationals (DFN). The reason as to why I have chosen these groups is that this is the type of migrant that would be most likely to be affected by the Canada Border Service Agency (CBSA), who is responsible for sending migrants to detention. Irregular migration is the movement of foreign nationals that takes place outside the regulatory norms of the sending, transit and receiving countries (IOM, 2018). An asylum seeker is someone who is seeking safety from persecution or harms and awaits a decision on the application for refugee status (IOM, 2018). These groups of migrants tend to be fleeing from persecution and are being detained as a result of who they are rather than what they have done I have chosen this particular subject is because this is often a demographic of individuals who are being criminalized through immigration detention in Canada, with limited access to immigrant services and resources. Often, this group of individuals, (primarily irregular migrants or asylum seekers) tend to travel without documents, making the probability of detention high. These groups of migrants tend to be fleeing from persecution and are being detained as a result of who they are rather than what they have done.

Regarding methodology, the data collected for this study will utilize secondary research principles. Secondary research will be more significant for this study as opposed to primary research, not only as there is more flexibility to meet time and scope of this paper, but is also suitable for an initial exploration of the topic. The data collected ranged from a variety of 
different sources such as the Government of Canada detention statistics, detention statistics from the Global Detention and the International Detention Coalition. One thing to note is that there was a significant lack of detention statistics presented. Although there was some information provided, there are still a number of missing figures that could have been beneficial for this study such as the reason for detention, exact ages, country of origin etc.

Furthermore, an analysis of the current literature will be used to assess the suitability of and recommend more in-depth follow-up studies. There is some existing literature available on restorative justice and immigrant communities, but there needs to be more work on this topic. As a result, secondary research for the present study will be gathered from a variety of sources. The primary source for academic articles will be accessed from Ryerson University Library and Archives, as well as the University of Waterloo Library. As the topics of restorative justice and Canadian immigration detention are contemporary and current, secondary sources such as newspaper articles will be valuable to explore the research topic. Lastly, there will be the utilization of Government of Canada web pages, documents as well as grey literature written by non-governmental organizations and settlement services. Government and grey literature data is essential for policy discourse analysis to assess the perspectives of how different sectors view problems.

\section{Background Information}

It is essential to provide context to the immigration detention system in Canada, who it affects and how immigration detention in Canada has evolved over the past couple of years. Initially, immigration detention was created as an emergency or temporary precaution that was 
subsequently made permanent (Mainwaring, 2018). Immigration detention refers to the detention of asylum seekers, refugees and other migrants who have been held either, upon entry or pending removal (Nakache, 2011). However, immigration should not be confused with criminal detention, where individuals are detained on the grounds of committing a criminal offence (Nakache, 2011).

Immigration detention in Canada is regulated by two significant statutes; the Immigration and Refugee Protection Act (IRPA) and the Immigration and Refugee Protection Regulations (IRPR), which are followed by a number of policy guides by the Canadian Border Services Agency (CBSA) and Immigration, Refugees and Citizenship Canada (IRCC) (Global Detention Project, 2018). Section 55 of the IRPA highlights that CBSA officers have the right to detain foreign nationals when an officer has reasonable grounds to believe the individual is inadmissible to Canada, danger to the public or is considered a flight risk from the immigration proves (Nakache, 2011). Furthermore, under section 55 of the IRPA, a CBSA officer may also detain a foreign national or a permanent resident at a port of entry in order to complete the immigration examination (Nakache, 2011). The IRPA provides the grounds for detaining foreign nationals and regulates the review of detention, conditions for release and the detention of minors and children (Global Detention Project, 2018). Under the IRPA, detention can involve holding migrants who, based on "reasonable grounds to be inadmissible and is a danger to the public, are unlikely to appear for an examination/admissibility hearing, or does not meet the satisfaction of proving individual identity of a foreign national" (IRPA, DIV $6 \sec 51(2)$.

Immigration detention is not a punishment for a crime (Nakache, 2011). Although, migrants with irregular status may be subject to immigration detention as they are in 
contravention of immigration laws and regulations, "infractions of immigration laws and regulations should not be considered as criminal offences" (OCHCR 2000, pg13). Immigration detention is a measure to which individuals are deprived of their liberty but, without the procedural and substantive protections of the criminal justice system process (Nakache, 2011). The lack of protections in immigration detention requires that authorities be particularly watchful to ensure that detention is necessary for the circumstances (Nakache, 2011).

In the immigration context, there are a number of different definitions of detention that have emerged (Edwards 2011, pg. 8). For the purpose of this report, detention is understood as the "deprivation of liberty in a confined place, such as a correctional facility or a purpose-built closed holding centre" (Nakache, 2011 pg. 18). Furthermore, when individuals are detained in Canada, they are sent to either an immigration holding centre or a correctional facility which are sometimes maximum security prisons (Nakache, 2011). CBSA has used provincial prisons to house immigration detainees in when a person exhibits mental health or behaviour issues (Nakache, 2011).

Canada also does not have regulations that place a time limit to which individuals can spend in immigration detention - potentially, individuals could have been detained for up to 12 months without a judicial review (GDP, 2018). However, the governing legislation has since been revised to ensure a quicker judicial review (Bill C-31, 2012). Children may also be detained or 'housed' in detention as 'guests' to avoid the separation of families (GDP, 2018). Furthermore, migrants with psychosocial disabilities or mental health conditions can also be placed in immigration detention centres or maximum security prisons with little to no access to proper services or treatment (GDP, 2018). 
After a foreign national is detained, there is a review process. Those who are detained are referred to the Immigration and Refugee Board (IRB) for a review conducted by the Immigration Division (ID). This review takes place within 48 hours of the initial detention to determine whether or not detention should be continued or the individual should be released. A decision maker in the IRB will hear the review based on the official tribunal process which is often adversarial. The decision maker will hear arguments from a CBSA counsel as to why the individual should remain in detention, and the detained individual will have their counsel represent them and present the opposite. As outlined in figure 1, the decision can go either one of two ways. If continued detention is ordered, the defendant can appear for another hearing before the ID within seven days of the initial review. If there is a continued detention order, then there is a review every 30 days until there the IRB representative can be convinced that they no longer pose a threat to society. If it is found that there is no longer a need under the IRPA to continue detention, then the defendant is released. The decision maker can, however, release the defendant on conditions such as posting bail or with regular check-in to an immigration office.

In regards to designated foreign nationals, the timeline is different. Under the Immigration and refugee protection act section 20.1(1) (2002), a designated foreign national is someone who;

20.1 (1) The Minister may, by order, having regard to the public interest, designate as an irregular arrival the arrival in Canada of a group of persons if he or she;

(a) is of the opinion that examinations of the persons in the group, particularly for the purpose of establishing identity or determining inadmissibility — and any investigations concerning persons in the group - cannot be conducted in a timely manner; or

(b) has reasonable grounds to suspect that, in relation to the arrival in Canada of the group, there has been, or will be, a contravention of subsection 117(1) for profit, or for the benefit of, at the direction of or in association with a criminal organization or terrorist group.

(Immigration and refugee protections Act, S 20.1 (1), 2002) 
This section of the IRPA highlights the complicated process for designated foreign nationals in terms of detention because under IRPA Div 6 s. 55-3.1, if the Minister has made such a designation, officers must detain and/or arrest and detain without a warrant after entry into Canada (Immigration Refugee Protection Act, S. 55(3.1), 2002). Once detained, a designated foreign national is required to first report to an officer not more than 30 days and then once a year afterwards (Immigration refugee protection regulations, 2012). The treatment of designated foreign nationals in the immigration detention process leaves little to no chance to not automatically be placed in detention while leaving very long reporting times following their detention.

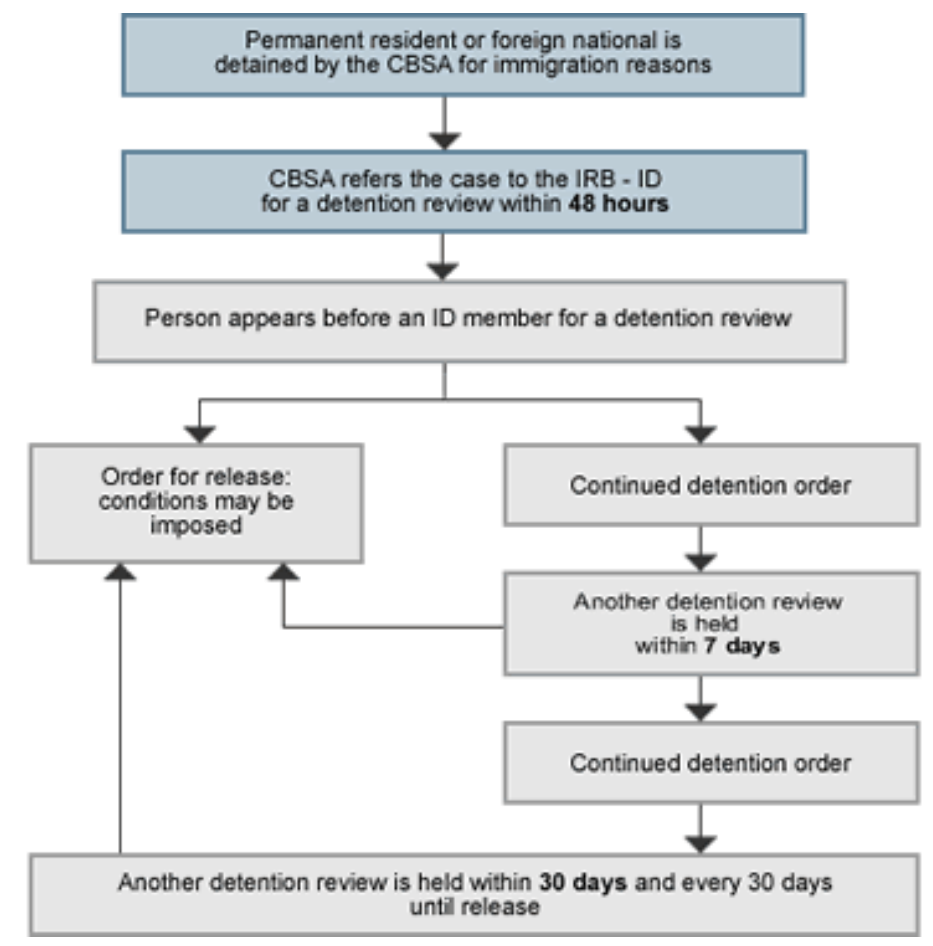

Figure 1 - Detention Review Process (graphic from IRB, 2018). 
The detention statistics in Canada has evolved over the past couple of decades in different ways. Examining the quarterly ${ }^{1}$ statistics from CBSA available in 2017 and 2018, there has been a total of 7,364 new individuals in detention from Apr-Dec 2017 (Q1 to Q3 ${ }^{1}$ ) with an average of 12.6 days spent in detention (CBSA, 2018). This is interesting to observe as new detained individuals during this the first three quarters of the current reporting period are already higher than the full 2016-2017 numbers by 1,113 individuals, making the fiscal 2017-2018 year potentially having the highest amount of detentions since 2012, when Canada had a total of 8,739 of new individuals in detention (CBSA, 2016). Furthermore, even though the number of irregular migrants is steadily decreasing (CBC, 2018), the number of those in detention is still increasing. This could have been as a result of the changes to Bill C-31 (Act to Amend the Immigration and Refugee Protection Act (IRPA), 2012) which provided for mandatory detention provisions, allowing for Canadian detention centres to house a variety of de facto mandatory detainees (Silverman, 2014). The amendments to Bill C-31 allowed for "migrants posing flight or security risks or who have not proven their identities and who could not find sureties in Canada - post-sentence, pre-removal individuals are transferred directly to prison to await deportation.” (Silverman, 2014 pg. 28). These amendments, arguably, reflect a particular migration agenda that seeks to deter further immigration. This development can be used to highlight the current nature and relevance of this topic. As a result of these irregular or illegal border crossings, individuals are often detained for reasons including that they pose a threat to the general public, are considered to be a flight risk, they cannot provide identification or they

\footnotetext{
${ }^{1}$ In the Government of Canada, quarters are broken down as follows: Q1 (April 1 to June 30); Q2 (July 1 to September 30); Q3 (October 1 to December 31); Q4 (January 1 to March 31) Q4 data was not available on CBSA website at the time of this study (CBSA, 2018).
} 
are part of an "irregular" arrival as designated by the Minister of Public Safety and Emergency Preparedness (CBSA, 2018).

The IRPA has been previously criticized by NGOs, such as the Canadian Council for Refugees (CCR), who stated that "the Canadian Government has used the broad powers of the IRPA to detain, arrest and deport people based on mere suspicion or secret evidence" (GDP, 2018 pg. 9). This is significant because it suggests that there is a preconceived bias that is present within Canadian immigration law that is affecting the manner to which individuals are being detained.

\section{Literature review}

A literature review is critical as restorative justice programs for migrants who are in detention is a relatively new topic in terms of academic research. Although there is a general lack of publications in this area, approximately 60 reports, academic papers and media sources were reviewed. Literature was reviewed not only to explore previous work on the application of restorative justice to immigration issues, but also to provide specific information on the state of detention systems in Canada. The most relevant work includes reports written by the International Detention Coalition, Government of Canada, Canadian Border Service Agency, academic papers and numerous forms of grey literature from various non-governmental organizations and newspaper articles. The following sections highlight the most significant findings from the literature, such as the present issues surrounding immigration detention in Canada and in general, current efforts to alleviate issues in immigration detention and the application of restorative justice to immigration detention. 
The review will begin with a preliminary overview of Canadian policies and frameworks, with a specific focus on alternatives to detention commitment. Following this, I will highlight the critical literature and content surrounding restorative justice as well as current applications to restorative justice and detention. This review will be followed by an analysis of some of the current issues of detention and why other options, including the use of restorative justice principles, need to be considered. The use of restorative justice programs in immigrant detention centres have the potential to, not only advance the area of immigration research but also, provide creative solutions to alleviate the current problems surrounding detention.

\section{Issues surrounding Immigrant Detention as presented by literature}

The literature on immigration detention highlights some critical issues. Some of these issues include detainee mental health consequences as a result of immigration detention, children in immigration detention, the institutional strain and cost of immigration detention and the impact on individual human rights. Furthermore, there are many arguments that immigration detention itself does not even deter irregular immigration. There have been a number of key literary sources that highlight these issues. These issues are significant in addressing the current problems that exist in immigration detention. By highlighting and analyzing these present issues, a better argument can be made for the incorporation of alternatives to detention and restorative justice.

\section{Detention does not deter Irregular Immigration}

Governments are concerned with protecting the safety and security of their people, and irregular immigration is seen as a threat. This threat and its unpredictability was a driver for the creation of the detention system. However, there is a concern as to whether or not detention has 
value as a deterrent to irregular immigration, as is often assumed. A significant report, recently released by the International Detention Coalition (IDC), highlights some of these. IDC presents that "there is no empirical evidence that the threat of being in detention deters irregular migration" (IDC, 2018, pg. 3). This is because migrants are often not fully familiar with a country's immigration laws and regulations because their primary focus is to reach a country of safety and security. Refugees also often choose countries by where they already have family in and might not consider those countries' specific rules. For many refugees that fit this profile, the threat of detention or, the lack of knowledge of the detention rules will not necessarily be a deterrent and suggest that irregular immigration should be expected, especially when restrictive asylum and border policies exist. Additionally, the UNHCR also recognized the lack of evidence that supports immigration detention as a deterrent for irregular migration and individuals seeking asylum (UNHCR, 2011). Especially, in regards to claiming asylum, the UNHCR highlights that seeking asylum in no way, shape, or, is a criminal act and therefore asylum seekers should not be penalized for seeking out asylum through detention (UNHCR, 2011). The process of immigration detention is criminalizing a group of individuals, who in the case of irregular migration and/or asylum seekers, are fleeing trauma, violence and persecution. Detention in the eyes of the migrant is a penalty for wanting a safer and secure life.

\section{Institutional and Administrative Inconsistencies}

Another significant issue surrounding immigration detention is that immigration detention systems do not support case resolution, which is the process that takes an asylum application to a conclusion (IDC, 2018). Certain scholars argue that detention affects the efficiency of the institutional administrative processes like integration (Bloomfield, 2016; IDC, 2018; UNHCR, 2011). What this means is that migrants' ability to access outside [of detention] 
services can prevent individuals from organizing themselves administratively and as a result, become lost in a complicated bureaucratic process. The ability to access services will be beneficial in terms of integration as detainees who are not familiar with a 'Canadian' way of life can begin to acclimate to society.

The amount of social services that is available to an individual is generally dependent on Government facilities and funding. The more funding that is available for social services in IHC, the more opportunities for future integration and immediate service needs. The three largest IHC in Canada are located in Vancouver, B.C, Toronto, Ontario and Laval Quebec. However, a review of the list of services that are available reveals inconsistencies between all three. In Vancouver, there is next to nothing provided as its primary intention is to be a $24-48$ hour detention facility (CBSA, 2018). However, according to the Vancouver Sun, there is a promised renovation of the Vancouver facility as a direct result of the death of Lucia Vega Jiminez, a detainee who died in the Vancouver facility in 2014 (Mahichi, 2018). The IDC and many other sources highlight research that demonstrates the correlation associated with detention and mental health problems such as depression, anxiety and post-traumatic stress disorder (IDC, 2018). The new building is promised to provide social services for detainees including medical, mental health and spiritual services (Mahichi, 2018). The new building is also promised to provide natural light, proper air ventilation and outdoor recreational space, which is not provided at the present location (Mahichi, 2018). The lack of a proper standard for facilities suggests a significant issue in comparison to international detention standards (Mahichi, 2018). According to the National Immigration Detention Framework (NIDF), the new B.C. IHC will be relocated to a previous Government building in Surrey and will be completed in 2019 (CBSA, 2018). 
The Toronto and Laval IHC are much larger than the Vancouver detention centre. Both institutions should provide consistent and similar services. However, some inconsistencies are still noted. For instance, it is good that both facilities have physicians, nurses and psychiatrists are available. However, there is only 24-hour service in the Toronto, and not at the other facilities (CBSA, 2018). The Laval IHC lists a large cafeteria providing 3 meals with a day, a barber shop, and gym, whereas the Toronto location has a 'service kitchen' to provide meals to detainees and provides specialized schooling for children (CBSA, 2018). All of these are, arguably, great services, but they are not consistent across both institutions. An aspect that is lacking from all IHC is services the respect and protection of LGBTQ2+ migrants. For example, there are no non-gender binary rooms available for individuals who wish to not identify gender. This is significant because if there is a migrant who was persecuted based on sexual orientation or gender, being placed into an environment such as this could trigger further trauma.

Researchers have determined that compliance to an administrative system of immigration detention is closely related to the trust that built between the migrant and the administration/institution (IDC, 2018; UNHCR, 2016; Bloomfield, 2016). In this case, trust is difficult to build between administration and migrant if the facility services are lacking and/or inconsistent. Furthermore, previous deaths in IHC can also prevent future trust building and reassurance of safety. Trust is a significant aspect of the quality and success of the detainees because, again, researchers have linked trust to an individual sense of control which impacts the individual's decision-making ability that can ultimately affect their future in Canada (Bloomfield, 2016). Institutional and administrative inconsistency is a significant issue that can be easily prevented by being consistent across all IHC's. 


\section{Vulnerable Foreign Nationals}

Additionally, there is a significant impact on vulnerable foreign nationals, especially those who have experienced trauma and who are in immigration detention. There is an overwhelming amount of evidence that points to the impact of the violation of individual human rights as a result of immigration detention (UNHCR, 2011). Detention, on the whole, can interfere with human rights, and multiple violations are possible. International human rights law "establishes the right to liberty and protection from arbitrary detention" and detainees are at further risk of this violation because of the fact of their placement in an institution or confinement (IDC, 2018 pg. 5). Furthermore, the Canadian Charter of Rights and Freedoms, section 9 states that "everyone has the right not to be arbitrarily detained or imprisoned" (Canadian Charter of Rights and Freedoms, 2017 section 9). This highlight the principle that arbitrary detention does directly violate individual legal rights.

For example, one large impacting factor on human rights is the effect detention has on mental health and quality of life. Immigration detention, globally, has been struggling with the elimination of children in detention. Child-detainee health in regards to their overall cognitive and emotional development (IDC, 2018) is a significant concern. Section 60 of the Immigration and Refugee Protection Act (IRPA) states that "as a principle that a minor child shall be detained only as a measure of last resort taking into account the other applicable grounds and criteria including the best interest of the child" (Silverman, 2016 pg. 119). This is problematic as it further proliferates the chances that a migrant child entering Canada might be detained. On Wednesday, June 27, 2018, more than 2,000 Canadian healthcare organizations and providers signed an open letter that calls on the Canadian Government to stop detaining immigrant children (Keung, 2018). This letter also highlights a vital statistic of over 162 children in immigration 
detention in 2017 (Keung, 2018). Health practitioners also acknowledge the increase in mental health symptoms as a result of immigration detention, regardless of the length of stay in adults and children (Keung, 2018). This includes elevated rates and diagnoses of depression, anxiety, PTSD, regression in developmental milestones (for children) and sleep disruption (Keung, 2018). However, this not limited to children. There is also a lot of evidence supporting that immigration detention impacts mental health and overall well-being of adult migrants. One of the largest impacts on individual mental health is the lack of knowledge regarding the end of their detention (UNHCR, 2011). Furthermore, there is also the ripple effect of trauma once they are able to leave detention. Mental illnesses such as PTSD can be a direct result of detention. One study found that that migrant who has been detained are five times more likely to suffer from PTSD and PTSD symptoms three years post-release remained very high (Cleveland, 2018). For individuals from vulnerable populations who are feeling traumatized as a result of human rights violations, being detained can re-traumatize and can impact further development of mental illnesses as a result (Marouf, 2017).

Furthermore, many migrants and asylum seekers who are detained often feel as though they are being punished for crimes they have not committed (Bloomfield, 2016). A recent study showed that migrants in Swedish immigration detention centres consider detention to be imprisonment with experiences similar to criminal prisoners (Bloomfield, 2016). Feeling unjustly imprisoned like a criminal negatively the impacts individual well-being and mental health. "They are torn from their communities, separated from their families and friends, locked in cells, forced to wear restraints and orange jumpsuits, subjected to strip searches, and constantly monitored." (Marouf, 2017 pg. 4121). The experience of criminals and immigrants in detention are evidently quite similar. 


\section{Immigration Detention is Costly}

Immigration detention is also expensive (financially), mainly due to the high capital cost of buildings to hold detainees with the necessary infrastructure and staff (IDC, 2018). The IDC has released a report which highlights that detention is significantly more costly than using services provided by community-based NGOs (2018) which have also shown to be a better alternative for migrants. According to the IDC, Canada spends approximately CA $\$ 179$ per individual per day on detention, compared to CA $\$ 12$ a day per person for alternatives (IDC, 2018 pg. 11). These alternatives to detention can be a more cost-efficient option that the Government of Canada should consider. Alternatives to detention are not only shown to be costeffective in Canada but can present cost savings for other countries, such as the US and Australia, two of the largest hubs for immigration (UNHCR, 2016). Cost savings that are presented can be a good way of channelling savings into other social services that can benefit detainees.

\section{Indefinite Detention}

Canada is one of the few western nations who does not have an outward time limit on immigration detention (Hussan, 2014). This can be interpreted in one of two ways. Firstly, one could argue that indefinite detention highlights Canadian commitment to the 1951 Convention relating to the Status of Refugees, in the sense that detention provides a protected area ensuring physical safety and security for individuals who are unable to be sent back to their home country. This can be because the said country is unsafe, dangerous or the migrant is at risk of further persecution. However, indefinite detention also means that an individual could spend years in Canadian immigration detention centres, with no understanding of when they might be released or deported (Hussan, 2014; Silverman, 2016; 
Bloomfield, 2016). Detention in these cases is often viewed as a violation of human rights, not only internationally but according to Canadian standards. In the case of Charkaouiv Canada, the Supreme Court of Canada ruled that detention without review for 120 days was a direct breach of section 9 and section 10 of the Charter of Rights and Freedoms (Silverman, 2016; Thawaites, 2017).

The possibility for indefinite detention can lead to an overall increase in detainees and places an administrative strain on IHC such as insufficient staff, and the lack of space Lack of space is often resolved by sending detained migrants to prisons (Hussan, 2014). The use of prisons in lieu of IHC is a significant concern as the maximum security facilities were designed and built to contain criminals. Placing migrants in prisons when no crime is committed can further proliferate the discourse that migrants who are in immigration detention are 'criminals' and a danger to the public. In 2013, there were 191 migrants, held in a maximum security prison in Lindsay Ontario, who went on a hunger strike to protest the conditions to which they were being detained (Kennedy, 2017). Migrants who were locked away in these prisons were treated the same as the rest of their inmates, including being stripped searched and forced to wear orange jumpsuits (Kennedy, 2017; Harris, 2017; Pfeffer, 2016).

Since 2000, approximately 16 individuals have died in immigration detention centres in Canada, with four of those deaths occurring after 2016 (MacLean's, 2017). MacLean's highlights the concerning issue of the general quality of life that individuals are faced with while in immigration detention. Many of these 16 individuals did not have any criminal record but were nonetheless incarcerated in maximum security prisons that significantly decreased their quality of life and impacted their trauma and mental health. Detention in prisons limits 
individuals' access to health care, counselling, legal aid, not to mention the impacts of additional 'co-mingling' with proven criminals. Certain literature highlights that individuals should not be criminally sanctioned for civil matters (Quigley, 2013). Furthermore, according to Nakache, statistics show that $36 \%$ of detained asylum seekers and failed refugee claimants, who are being held in prisons, are considered to be "low risk" (Nakache, 2011 pg. 74). Individuals who are considered to be a low risk should not be held in prisons.

According to section 6 - 1 of the Canadian Charter of Rights and Freedoms, "Every citizen of Canada has the right to enter, remain in and leave Canada" (The Canadian Charter of Rights and Freedoms, 1982) which has made the argument against indefinite detention difficult since migrants who are in immigration detention are not citizens of Canada. However, there have been legal challenges in the past that fight back against indefinite detention of foreign nationals. For example, in case Andrews v. Law Society of British Columbia, the Supreme Court ruled on non-citizen status as 'grounds of discrimination' according to section $15-1$ of the Charter; "Every individual is equal before and under the law and has the right to the equal protection and equal benefit of the law without discrimination and, in particular, without discrimination based on race, national or ethnic origin, colour, religion, sex, age or mental or physical disability" (Thawaites, 2017 pg. 228). However, Andrews v. Law Society of British Columbia does not highlight the discrepancies between section 6 and section 15 of the Charter (Thawaites, 2017). This causes further ambiguity of detainee rights. However, in 2015, the Ontario Superior Court of Appeals ruled that in Chaudhary v Canada that migrants have a right to apply for habeas corpus relief, or the right for individuals to seek review and relief of incarcerations caused by the state (Silverman, 2016). Some scholars argue that while there are routine bail hearings for detainees, ultimately the bail hearings are organized in a way that prevents detainees from 
accessing habeas corpus rights (Silverman, 2016). However, in Canada, for certain categories of newcomers who have been labelled by the Canadian government as 'Designated Foreign Nationals,' there is the possibility of mandatory detention for up to one year without review (Silverman, 2016). Within section 20.1 (1) of the IRPA, the;

"Minister may, by order, having regard to the public interest designates as an irregular arrival the arrival in Canada of a group of person if he/she; (a) is of the opinion that examinations of the persons in the group, particularly for the purpose of establishing identity or determining inadmissibility — and any investigations concerning persons in the group - cannot be conducted in a timely manner; or (b) has reasonable grounds to suspect that, in relation to the arrival in Canada of the group, there has been, or will be, a contravention of subsection 117(1) for profit, or for the benefit of, at the direction of or in association with a criminal organization or terrorist group" (IRPA S. $20.1-1$ )

Immigration detention globally and in Canada has proven to be expensive and a violation of an individual's fundamental human right, especially with the prolonged practice of indefinite detention. These issues surrounding immigrant detention can no longer be ignored, and better and more creative solutions are needed immediately. Fortunately, these issues have grabbed the attention of the Canadian Federal Government, which resulted in the creation of a new National Immigration Detention Framework.

\section{Canadian Immigration Detention Policies and Framework}

In Canada, the two main legal statutes that overlook detention policies are the Immigration Refugee Protection Act and the Immigration Refugee Protection Regulations. Both statutes outline specific legal guidelines that encompass immigration detention. However, the National Immigration Detention Framework (NIDF) was developed to better define the Canadian policy for immigration detention. Still relatively new, the NIDF was enacted in 2017 by CBSA 
to primarily to "create a better, fairer immigration detention system that supports the humane and dignified treatment of individuals while protecting public safety" (CBSA, 2018 pg. 1). The NIDF identifies four pillars on which its framework is built upon; partnerships, alternatives, mental health and transparency (CBSA, 2018). For this framework to succeed, CBSA has allocated 138 million dollars over the course of five years (CBSA, 2018).

The four main principles of the NIDF are transparency, partnerships, mental health and alternatives to detention. Of this new framework, the principle of transparency is significant for a number of researchers in regards to the availability of detention statistics. Since 2016, CBSA has been updating detention numbers and statistics to its website quarterly (CBSA, 2018). The numbers are unclear as to how many individuals are leaving detention facilities every year. Furthermore, the numbers related to the demographics of the new detainees are also unclear. In this case, demographics goes beyond ethnic representation, but rather the proportion of individuals who are migrants looking to live in Canada. Although I would expect the number of visitor detainees would be small and possibly insignificant, CBSA does not provide any data to establish the number, leaving uncertainties in assessing statistics for the groups relevant for the present study.

The breakdown of demographics of detention numbers should be the next priority for CBSA to include within their transparency agreement of the NIDF. Partnerships within the NIDF refers to CBSA's engagement with various stakeholders to advise on various aspects of development, design and implementation (CBSA, 2018). Consultations with key stakeholders, NGOs, provincial partners will work with CBSA to provide regular feedback and accountability (CBSA, 2018). CBSA continues to be committed to improving detainee well-being and mental 
health by ensuring secure, safe and humane detention conditions by improving the accessibility of mental and medical health services (CBSA, 2018). Furthermore, there is an increased initiative to limit detaining those living with a mental illness by expanding the availability of alternatives to detention (CBSA, 2018). Alternatives to detention are arguably the key pillar of the NIDF and constitutes the primary focus of this study.

\section{Alternatives to Detention}

Alternatives to Detention (ATD) is a term that can be interpreted in a variety of different ways. The International Detention Coalition (IDC) maintains a broad definition that includes a variety of different options for a State to avoid detention (IDC, 2018). The IDC defines alternatives to immigration detention as "any law, policy or practice by which persons are not detained for reasons relating to their migration status" (IDC-There is an alternative, 2018 pg. 1). The recent push towards implementing ATD globally has been a direct result of the development of more restrictive migration policies and harsher precautions against irregular migration (Bloomfield, 2016).

As part of Canada's National Immigration Detention Framework (NIDF), a key pillar is the identification of Alternatives to Detention. As stated within the CBSA's policies, migrants should be only detained when the necessary grounds exist and, there are no alternatives available that mitigate the risk posed by the detainee if released (CBSA, 2018). I agree with this statement; however, I would argue that there should always be alternatives available to detention. The Citizenship and Immigration Canada Enforcement Manual (IRCC, 2018; CBSA, 2018) states that border officials and officers are required to be aware that ATD exists. Officers must also be aware and consider ATD and ensure detention is only used as a last resort for vulnerable groups, such as the "elderly, pregnant, sick, handicapped, mentally ill, and with behavioural 
problems...Where safety or security is not an issue" (IDC, $2018 \mathrm{pg} .13$ ). When deciding to detain or release an individual, officers must consider the existence of ATD, "detention is feasible where ATD is not available to mitigate any risk to public safety or flight risk" (IDC, $2018 \mathrm{pg}$. $18)$.

Currently, CBSA is creating an expanded ATD plan to allow for risk-based, nationallyconsistent programming for individuals who could potentially qualify for release from detention (CBSA, 2018). To ensure that this is the case, CBSA will provide its officers with an 'expanded' set of tools and programs that will allow for more efficient management of migrant needs while simultaneously ensuring the public's safety (CBSA, 2018). CBSA's ATD framework will include;

"A Community Case Management and Supervision (CCMS) program that will align incommunity support services with individuals' needs to mitigate any risk factors; a nationally available voice reporting system that will enable individuals to comply with reporting conditions imposed by the CBSA or the Immigration and Refugee Board (IRB), by using voice biometrics to report to the CBSA at a prescribed interval; and, expanded electronic supervision tools such as the use of GPS Electronic Monitoring on a pilot basis." (CBSA, 2018 para 3)

Community case management is a strong component to ATD as it allows for detainees to live independently in the community to resume a more 'normal' routine (UNHCR, 2016). The UNHCR has listed a number of countries who have already been using community case management systems as a form of ATD. For example, in Chile, asylum claimants are issued renewable temporary stay permits with work entitlements (UNHCR, 2016, Sampson, 2013). While Chile is one example, many countries have also adopted open accommodation options are available that provide a range of different social services directly on site (UNHCR, 2016). For instance, in Hong Kong, as many as 5,000 claimants have benefited from housing initiatives that 
are run by NGOs (UNHCR, 2016). Ideally, community case management is ideal for CBSA to adopt because it not only does it allow for asylum and refugee claims to be considered, it prioritizes informed decision making and the well-being of the migrant. Another example of this can be examined through the ATD system in Sweden. In Sweden, two caseworkers are assigned to an appointed asylum-seeker as a means of dividing the administrative asylum process and making referrals to medical care and other social services that might be needed (UNHCR, 2016). ATD systems such as these ensure not only that claims are efficiently processed but that there is social reassurance that can sooth some of the anxieties that arise when moving to a new country.

Canada's aim for creating the ATD program aligns directly with its commitment to the UNHCR's Global Detention Strategy Guidelines as a means to ensure that ATD is considered in all cases prior to being detained (CBSA, 2018). The Guidelines include the elimination of children in detention, ensuring that alternatives are available and implemented in practice and the conditions of detention meet international standards (UNHCR, 2014). As discussed below, programming such as this aligns with restorative justice principles as the option is available for those to mediate their case with CBSA officers.

That being said, ATD programs are not a new phenomenon. Many countries around the world have created their own ATD programs, some of which have been developed further and are more efficient than ATDs in Canada (IDC, 2018). This is mostly because ATD programs outside of Canada are older and more established whereas Canada's ATD program is still relatively new. For example, by the end of 2011, all member states of the European Union (EU) have introduced ATD programs into their national legislation (Sampson, 2013). Working ATD programs into national legislation is a result of the increased interest in reducing detention in EU countries. Regarding Asian nations, Japan has made significant progress to its ATD 
programming as a result of increased rioting and violence within its immigration detention facilities (Sampson, 2013). After April 2010, the Japanese government had concluded that all children would be released from detention while creating a new policy to prevent the detention of children in the future (Sampson, 2013). In Canada, despite the recent (2017) increased concern of the treatment of migrant minors, children are still being detained but "only as a last resort" (CBSA, 2018 pg. 1). Japan has been successful in reducing its overall immigration detention numbers and has created detention pilot projects surrounding vulnerable groups and developed significant partnerships with NGOs (Sampson, 2013). After Japan made significant changes to their detention system, their overall detention numbers reduced and they developed partnerships with local NGOs to continue the support for ATD programs (Sampson, 2013). It is important to note as well that in Japan, a minor is considered to be anyone who is 20 years old and younger (GDP, 2018) - Japanese statistics might include some who would be considered as adults in other countries. According to the Global Detention Project, as of 2012, there were only five minors recorded to be in detention facilities, and by 2013, all detention centres in Japan received regular visits from community NGOs to monitor them (GDP, 2018). As of 2017, the GDP has not listed any statistics on minors who are in immigration detention (GDP, 2018). The International Detention Coalition has identified, in a recent report, over 250 examples of ATD programs in over 60 different countries (GDP, 2016). Along with Japan, other countries, including Malta, South Africa, The United Kingdom, China and many others have all committed to eliminating child detention. In regards to foreign nationals, there is a number of ATD programs in place, but they are not as prominent. There has not been nearly the same amount of success in terms of reducing an adult to child detention, but it is slowing become more widely used and more successful. 
Although Canada is arguably behind in comparison to others around the world, ATD principles and guidelines are being developed by civil society organizations based on the UNHCR guidelines. The Canadian Council for Refugees (CCR) developed a particular framework in regards to alternatives to detention. Along with the UNHCR's detention guidelines that liberty is a fundamental right, CCR believes that any alternatives to detention must not lead to increased or extended enforcement measures, and should not be drawn from criminal models (CCR, 2014). According to the CCR, the most effective method to ensure compliance within the Canadian immigration rules is to provide comprehensive case support, including access to proper legal representation, accessibility and delivery of information as well as presenting the migrant with all of their options (CCR, 2014). The UNHCR highlights that traditional bail systems are also a good alternative for states to practice (2016) and is a current method of ATD that has been available in Canada.

The Toronto Bail Program (TBP), for example, continues to attract significant attention on a national and international level (CCR, 2015). The TBP is an independent tribunal that receives funding from CBSA and provides supervision of migrants who would otherwise be detained. The TBP presents an alternative to detention, which is a core value in CBSA's National Immigration and Detention Framework (NIDF). The TBP provides an example of how regular review of conditions within detention centres could be implemented. The program itself has been operating since 1996 (IDC, 2018). The TBP identifies eligible detainees through a screening and assessment process. Once an individual is identified, the TBP then supports their application for release on bail. Migrants who are in detention and are considered eligible are those 'higher risk' individuals who are facing possible deportation after completing a prison sentence, refused refugee claimants (those waiting deportation or appeal) and asylum seekers detained due to 
issues of credibility and flight risk (IDC, 2018, CCR, 2015). Individuals who are initially placed in the program undergo intensive supervision and are required to check in regularly. This process is intended to build trust between the participants and the caseworkers. Trust building for cases is significant because when trust is being built between the participant and caseworker, there is more emphasis on a successful outcome by respecting the process and potentially a higher chance for the individual to be released. The program is relatively inexpensive, costing about CA $\$ 10$ per person/ day, compared to CA $\$ 179$ per person/per day for Canadian detention (IDC, 2018).

CCR argues that the TBP and other similar programs like it have particular advantages to them (CCR, 2015). For example, CCR describes that;

"A well-established, credible program can secure release for people who would otherwise remain detained, can provide significant support to individuals postrelease and can develop specialization and community connections in relevant areas such as addiction and mental health that can be extremely valuable for individuals with those needs.” (CCR, 2015 pg. 1)

However, it is also important to highlight some of the concerns that CCR has listed in regards to the TBP. Primarily, CCR believes that TBP is a program foundationally designed within the criminal justice model, which then demands strict reporting requirements based on the criminal model and therefore inappropriate for immigrant detention (CCR, 2015). It could be argued that restorative justice is also a system for criminal justice, but I would suggest that the situation is entirely different. The traditional criminal justice model is adversarial whereas restorative justice, when applied to criminal justice, actually proposes a different model based on assessing needs and restitution. Although using elements from a traditional criminal justice model might 
not be appropriate for immigration, the new restorative justice model is different and could be appropriately applied to many issues, including immigration detention.

CCR claims that the criteria for eligibility for TBP are not clear or transparent and often comes across as arbitrary (CCR, 2015). Migrants looking to qualify for the TBP may also experience even longer wait times which might increase the overall time spent in detention (CCR, 22015). Lastly, as the name would suggest, the TBP is only available in Toronto, thus creating further inconsistencies (CCR, 2015). TBP is also being funded directly through CBSA which can be problematic because there could be issues of independence (CCR, 2015). For example, this may include questions as to CBSA's involvement and influence over who is eligible to participate in the program as well as the sharing of private information with CBSA (CCR, 2015).

\section{Restorative Justice}

Similar to ATD, restorative justice has many working definitions and interpretations. The definition that I have chosen to highlight for this study is from Howard Zehr, a leading scholar in restorative justice. He describes restorative justice as "a process to involve, to the extent possible, those who have a stake in a specific offence and to collectively identify and address harms, needs, and obligations, to heal and put things as rights as possible.” (Zehr, 2011, pg. 29). The primary goal of restorative justice is to provide an alternative framework or lens for thinking about crime and justice. Crime, as stated by Zehr, is a violation of people and interpersonal relationships (Zehr, 2015). Although restorative justice is closely linked to the Canadian criminal justice model, it can also be applied to a non-criminal population, such as migrants who are being detained. The reason for this is that restorative justice is not only a program but an 
ideology. Howard Zehr, I believe, accurately describes restorative justice as a compass and not a map. Restorative justice programs that exist currently within the criminal justice system embody many qualities of a restorative justice ideology. Often, restorative justice scholars dispute whether or not restorative justice is a school of thought, theoretical perspective or a specific type of programming. For this study, restorative justice will be looked at as a theoretical perspective as well as alternative and practical programming. The reason as to why restorative justice is not a particular established program is that it continues to evolve. However, there are universal principles that restorative justice acknowledges which can be applied to existing programs such as ATDs.

A restorative justice lens has five key principles or actions:

1. "Focus on the harms and consequent needs of the victims, as well as the communities' and the offenders';

2. Address the obligations that result from those harms (the obligations of the offenders, as well as the communities' and society's);

3. Use inclusive, collaborative processes;

4. Involve those with a legitimate stake in the situation, including victims, offenders, community members, and society;

5. Seek to put right the wrongs". (Little Book of restorative justice, 2011 pg.26)

A couple of essential definitions need to be provided. Who are victims? Victims in the criminal justice world are those whose needs are not being met by the justice system (Zehr, 2011). Victims can often feel ignored, neglected or abused by the criminal justice process (Zehr, 2011). Within the traditional criminal justice system, crime generally involves the state and the offender, with the victim being often left out of the process. Who are offenders? Offenders are also another significant priority for restorative justice practitioners. Offenders are held 
accountable to the state until a 'punishment' of some sort is issued to them. Punishment is often a fine, jail or both but usually does not directly address the victim's specific needs. In the case of immigrant detention, we need to question whether the detained migrants are the victim or the offender. Migrants, in detention (although they are not criminals), could be considered as both an offender and a victim depending on the perspective. For example, Migrants who are arbitrarily detained can be considered to be victims of an oppressive state. The state (and some in public) however, would often perceive migrants, who have outstayed their visa or didn't provide adequate documentation, as offenders who have committed an offence against the state. This situation of being both victim and offender has its parallels in criminal justice. For example, a person that commits a crime would be the offender. However, it could be argued that his path leading to the crime could be the result of society's many injustices (such as racism, poverty, lack of social support and opportunity etc.) making that person a victim of a failed society. Restorative justice principles can recognize these dichotomies and would, therefore, apply to many of the immigration detention situations. The application of the term 'offender'is more symbolic rather than a hard label in the case of immigration detention. This is to prevent the further criminalization of a vulnerable demographic. However, for the purpose of consistency, I will continue to use the term 'offender' to respect the fundamentals of restorative justice.

Zehr uses a significant analogy that is worth highlighting. He describes restorative justice as a wheel where the hub is the central focus to put right the wrongs and harms (Zehr, 2015). In the context of immigration detention, restorative justice would define wrongs and harms as, among others, the separation of children and parents, development of trauma and mental health experienced through the detention process and the consistent criminal treatment of a demographic of people who are not criminals. The spokes of the wheel highlight essential 
elements that make up the integrity of the wheel. Those elements include harm and needs of individuals, obligations, involving stakeholders and the use of a collaborative and inclusive process (Zehr, 2011). If we stick to this analogy, restorative justice programs in immigration would be the tires of the wheel, keeping the elements aligned and moving forward down the road. It is within this capacity where restorative justice principles could be applied to immigration issues, and alternatives to detention can thrive.

Restorative justice, as a theoretical perspective or ideology, is not criminal justice, per se, but presents a new way of looking at the Canadian Criminal Justice System and this viewpoint could also be applied to immigration detention as a whole. Restorative justice seeks to provide an alternative framework or lens for thinking about justice (Zehr, 2015). Providing an analysis of restorative justice as an ideology is intended to challenge readers and other scholars to change their perspective on immigration detention to that of a restorative justice outlook. This ideology can be challenging and difficult to adopt because it is inherently opposed to the conventional criminal justice and immigration detention approach that the broader society understands and recognizes. For a restorative justice approach to be accepted by the greater society, critics argue that, whether for criminal justice or immigration detention, there is a need to embrace the overall objective or 'goals' of the justice system' and work within its realities (Miller, 2008). Mostly, the criticism here is that, for restorative justice to work from ideology to reality, it needs to fit in with the reality of the Canadian criminal justice model and, in the application to immigration detention, the realities of Canadian Immigration law. It would be unrealistic to expect the entire system to adopt a restorative justice approach without understanding the capacity to which aspects of it might already currently exist within Canadian immigration detention alternatives. In adopting a restorative justice lens in viewing Canadian 
immigration detention, there can be an analysis made on the incorporation of restorative justice to its policies. Some scholars argue that restorative justice is philosophically liberal in the sense that its values are inherently emotional and, as a result, vague when determining accountability (Miller, 2008).

Miller argues that there needs to be an establishment of an accountability-based theoretical research program to further both theoretical and programmatic restorative justice initiatives (2008 pg. 262). Ideally, a more central leaning philosophical viewpoint is necessary to ensure that there is no ambiguity to how a restorative justice program can be accountable to public and private stakeholders. Miller, in contrast to Zehr, argues that some restorative justice scholars are overly critical of the criminal justice system and its programming agenda (2008). Others argue that restorative justice is already embedded throughout the criminal justice system. Generally, opposing theorists argue that the informal social control of restorative justice can be counter-intuitive to the efficiency of the current criminal justice system (Miller, 2008).

Restorative justice is morally liberal and contrasts with a conservative approach to crime. Liberal ideologies in this sense refer to more social priorities, and conservative ideologies refer to more totalitarian approaches. For example, Miller says that a conservative perspective of criminals revolves around the notion that crimes are committed due to lack of self-control, are intended to 'beat the system' and use poverty as an excuse for the crime (2008). The overly humanitarian nature of restorative justice would argue criminals have been failed by the state, social factors and other outside elements are elements to consider for the offender's reason for committing a crime. Miller presents an interesting point that for this reason: it is difficult to discuss restorative justice on an ideological level (Miller, 2008) and that morally, it is challenging to analyze. Primarily, in this chapter, I will discuss the essential pillars of restorative justice, its foundations 
and the applicability to immigration detention. Furthermore, the ideologies of accountability will be addressed throughout this chapter as it can directly impact funding allocations for future programs.

The three pillars of restorative justice as described by Howard Zehr, are harms and needs, obligations and engagement (Zehr, 2015). The first pillar, 'harms and needs,' suggests that justice begins with a concern for victims and their needs and an objective to repair human harm as much as possible, both concretely and symbolically. As previously mentioned, the allocation of who is the victim and who is the offender can be challenging to quantify regarding immigration detention. Both parties can see themselves as being the victim with the other as the offender. However, that being said, this pillar is still significant as the victim-oriented approach requires that the justice system is concerned about the individual's needs. As previously discussed, there is some grey area when applying victim-offender labels to the Canadian state and the migrants who are in detention. This is because both the migrant and the state can simultaneously identify themselves as the victim and both can be seen as the offender. If both the Canadian state and the migrant see themselves as victims, arguably, they both have certain needs to be addressed to move towards reconciliation. Both parties, the state and the immigrant, need to identify what they need from each other to move forward. The determination of needs is not as it initially appears as one would assume. Yes, regarding immigrant detention, the detained migrant's needs are mostly that they would be to be released and be able to live in Canada without fear of persecution. However, some non-obvious needs can include mobility, access to proper healthcare and education, support services and respect from the immigration officials and staff. In terms of the State, migrants are detained for a reason, and that reason would be that the specific needs of the state are not met, such as the confidence of safety and security for the 
Canadian people, political needs and that no violations under the Immigration and Refugee Protection Act (IRPA) have been committed. This leads into the second pillar, which is 'obligations.'

Obligations refer to individual responsibility to make things right as much as possible both concretely and symbolically (Zehr, 2010). Traditionally, obligations refer to the offender's efforts to society to the right the wrongs that were committed. This is generally a joint effort by all parties involved. For example, is a someone were to vandalize a local church, the offender (as decided by the victim and community) might be obligated to clean up the vandalized wall and volunteer their time to the restoration of the entire establishment. However, regarding immigrant detention, the situation becomes tricky, as again, there are no offenders in the traditional sense. One method that could be applied is that the migrant can work and satisfy, at least, some of the needs of the state, to prove that they can be an asset to the Canadian community. This could be in the form of community service, volunteering or working in any capacity to show the state how they can be a valuable contributor to the Canadian community.

The last pillar, as described by Zehr, is 'engagement.' Engagement refers to the first parties, who were/are affected by crime, victims, offenders, members of the community, who are given significant roles in the justice process (Zehr, 2010). In the immigration context, community stakeholders who are working with CBSA in the creation of ATD could be involved. Conferencing is one method by which all stakeholders could participate. Conferencing works similarly to group mediation, where all parties can identify needs, discuss what needs have been met, what has not, and explore solutions and other actions required to move forward.

For a restorative justice approach in ATD to work within immigration detention, restorative justice needs to work within the boundaries of existing bureaucratic and legal aspects 
of the immigration detention system. This approach is not intended to polarize or be divisive by describing the current system as 'evil' and restorative justice as 'good.' Instead, both restorative justice and immigration detention need to work together for it to thrive and positively affect the Canadian government as well as the migrants who are affected.

\section{Current Literature and Restorative Justice Programs in Canada and around the World: \\ Themes and Critical Issues}

Restorative justice has progressively been considered to have a certain amount of appeal to policy-makers and practitioners (Johnstone, 2011). Primarily in Canada and other countries across the globe, restorative justice thrives within the youth justice system, but it is also beginning to be applied to older demographics as well (Johnstone, 2011). This growing popularity can be due to the success and increased use of restorative justice programs for youth. Cases that have involved restorative justice have been extraordinarily transformative and have had a powerful impact on all parties involved. The reason as to why restorative justice can be transformative is the empowerment, and recognitions participants feel after participating in restorative justice initiatives (Johnstone, 2011). However, that being said, why hasn't restorative

justice wholly taken over the criminal justice system? Some scholars believe this is because the culture of restorative justice is somewhat foreign to western nations. For example, crime in western nations is based on a public system of judicial punishment for crimes of violence and property (Johnstone, 2011). However, the approach towards a restorative justice approach is especially demonstrated in Canada in the Truth and Reconciliation Commission (TRC) which was created to acknowledge residential school experiences and promote healing and reconciliation for all those involved (TRC, 2007). This philosophy towards justice is restorative 
and demonstrates the possibility towards replicating the principles used in the TRC in other aspects of the Canadian justice system.

Currently, the implementation of restorative justice in immigration matters is limited. Some previous examples exploring this topic include a particularly interesting study done by Michael Sullivan that discusses restorative justice to legalize unauthorized migrants in the United States who have overstayed their visas (2017). Sullivan argues that there is no benefit to incarcerating and deporting long-term unauthorized migrants who are prepared to make recompenses for their immigration wrongdoings by applying applications of restorative justice.

First, Sullivan says that;

"victim-offender mediation can be used where there is an individual victim who is directly harmed by an unauthorized immigrant's use of false documents and, community reparative board to address the more diffuse harms arising from entering and remaining in a country without authorization. As ATD and deportation, these processes may provide unauthorized immigrants with an opportunity to make amends for immigration offences and further integrate into their adopted community." (Sullivan, 2017 pg.1)

Sullivan's work is a significant resource for this study. Not only has he applied a restorative justice approach to helping immigrant communities, but he also highlights the impact that these migrants have on their community. As mentioned in the quote above, Sullivan has also directly referenced alternatives to detention as a process to provide unauthorized migrants to make amends and contribute back into their community. Although Sullivan is referencing those migrants who have overstayed their visa and are at risk to be deported, a restorative justice approach to ATD programs can still be recognized as being a significant process that impacts migrants in detention. 
In Sullivan's study, he examines possible applications of restorative justice. Sullivan first suggests the use of victim-offender mediation where "there is an individual who is directly harmed by an unauthorized immigrant's use of false documents" (Sullivan, 2017 pg. 17). Sullivan highlights the victim-offender outlook that the offence is the falsifying of documents. However, restorative justice is also appropriate in this case because it recognizes that there are circumstances that compel individuals to falsify documents in order to secure to passage to the United States. Sullivan's use of language in using the term 'offender' is discouraging, as it is limiting to use such language when applying restorative justice to issues of immigration. However, Sullivan highlights a point that "If restorative justice places its core in the unification of victims and offenders, using this framework, there is no individual victim that could be brought into dialogue at a conference with someone whose only offence was entering a country without authorization" (Sullivan, $2017 \mathrm{pg} .75$ ). This is significant because Sullivan highlights the complexities involved in naming a victim and offender in situations such as these. Sullivan argues that a restorative justice process can humanize both parties to understand each other's perspective (2017 pg. 76). I would argue that when both parties are exposed to the effects of humanization of restorative justice, labels such as victim and offender are blurred and eventually dissolved.

Overall, the topic of restorative justice and immigration is relatively new and still needs to be explored further. However, I would argue that many models of restorative justice could be applied to the context of migrant detention. Currently, the United Nations Children's Fund (UNICEF) has an online 'Toolkit' for Diversion and Alternatives to Detention which is a resource for child protective specialists and others who work in this field (UNICEF, 2010). 
Although this toolkit was created intended for youth who have had experience with the criminal justice system, it presents an example of a large administrative body which is currently using and praising methods of restorative justice as a better alternative to incarceration. The toolkit was created as an online resource for practitioners and experts to refer to gather more information and resources on Alternatives to detention theories and programming that are currently being used. The Toolkit highlights a restorative justice approach as a viable example to alternatives to detention. Primarily, the toolkit was created to clarify what alternatives are, why they are important, provides practical guidance on how to implement alternatives and gathers together project examples (like restorative justice) and other resources to access (UNICEF, 2010). A toolkit such as this is relevant for immigration detention as it provides resources on how a restorative justice approach can be used in ATD. Within this toolkit, two significant handbooks are provided as a guide to restorative justice and alternatives to detention. The United Nations Office of Drugs and Crime (UNODC) has created one of the handbooks titled Restorative Justice Programs Handbook (2005), which explores a variety of topics from key definitions to program evaluations and the different uses of restorative justice programs (UNODC, 2010). The handbook outlines the use of restorative approaches, principles and safeguards, the implementation of restorative justice programs, the dynamics of restorative justice interventions, program operation and programme monitoring and evaluation (UNODC, 2010). This handbook's purpose is to help countries who are interested in criminal justice reform, and it can be used in a variety of different contexts. The handbook is intended to be in a quick reference format, provide an overview of key considerations in the implementation and use of a restorative justice approach to the criminal justice system (UNODC, 2005). 
The creation of a toolkit such as this one suggests a potential universal guideline that UNICEF has created, that could be smoothly transitioned to immigration detention. Rather than developing new legislation or guidelines entirely from scratch, the work by UNICEF could be used as an international model that can that we can look towards. Although UNICEF intended application for this toolkit in cases of youth in the criminal justice system, it is intended to provide evidence that restorative justice frameworks can work and are encouraged to prevent individuals (in this case youths) to be incarcerated, like migrants in immigration detention. This is significant as restorative justice programming is still relatively new to policymakers regarding strategic approaches or legislative processes. If UNICEF can recognize its significance and the benefits of restorative justice, then there is a capacity to which the program can expand and grow in other directions. The handbook goes into great detail about these nuances to help policymakers create a basis for new programming. This handbook should be referred to for the future creation of any restorative justice programming.

Having a restorative justice framework created on an international level is significant as it has the potential for providing a basis for consistency and universal restorative justice values within other forms of ATD programming. Although the UNICEF program itself does not directly involve migrant detainees, there is the potential for such an application. UNICEF's ultimate priority in adopting a restorative justice approach was to eliminate the detention of children around the world. These children can be detained whether they are foreign nationals travelling to seek asylum in a new country, or local citizens who have been wrongfully put in prisons.

The second handbook referenced in the toolkit acts as a reference for nation states who are developing criminal justice reform and was created by the United Nations Office on Drugs 
and Crime (UNODC, 2006). UNICEF and UNODC both claim that the handbooks and toolkit can be utilized in a variety of different contexts as both handbooks introduce the reader to restorative justice programs and process (2006). Both organizations also acknowledge the Handbook of Basic Principles and Promising Practices on Alternatives to Imprisonment as an excellent companion to the first restorative justice handbook (2005). As in UNODC's restorative justice Handbook, this second handbook covers a wide variety of topics such as alternatives to imprisonment, limiting the criminal justices system reach, sentencing and alternative punishments and methods on developing a coherent strategy. The handbook offered accessible information about alternatives to imprisonment within all stages of the criminal justice process and was written for government officials, NGOs and members of the community (UNODC, 2007). The application for restorative justice is possible and can extend beyond just children to all ages and demographics who are being wrongfully accused and detained. The partnership that UNICEF and UNODC have acknowledged through the creation of the toolkit and two handbooks highlights the capacity for collaboration. This is relevant for Canada as it provides the evidence from a globally respected institution that both restorative justice and alternatives to detention can be successful together. In particular, the UNODC handbook on ATD acknowledges that;

"Police and the prosecuting authorities should take the lead in diverting suspects out of the criminal justice system. Where the diversion is linked to mediation or even full restorative justice processes, a separate administrative structure is needed to facilitate these processes, provided either by the state or by non-governmental organizations partnering with criminal justice agencies". (UNODC, 2006 pg. 16)

The acknowledgement of collaboration between two agencies in focussing on restorative justice as an alternative to entering the criminal justice system is strong evidence that there is the 
possibility that, in the context of immigration, individuals should be given the option to pursue alternatives to detention.

On October 25, 2017, Manfred Nowak, an international human rights lawyer, was selected to lead the UN Global Study on Children Deprived of Liberty (IDC, 2018). What is significant about this study is that it will adopt a broad approach to address the deprivation of liberty for children in a variety of different areas, including immigration detention. Both qualitative and quantitative data will be collected on children in detention while highlighting an instance of good practices, such as restorative justice, which often works in the best interest of the child (IDC, 2018). Those involved in the study range from academics, other civil society organizations, and member states of the UN and the children themselves (IDC, 2018). This is a fascinating study for restorative justice and immigration as it directly involves the application of restorative justice to child-immigrant detention. The study has not yet been released but should be monitored and used as a critical point of research for future studies in the area of restorative justice and immigration detention.

Another international application of restorative justice can be examined through the European Forum of Restorative Justice. In early 2017, Bart Claes represented the European Forum for Restorative Justice at an ATD seminar in Bucharest, Romania. Claes presented on topics such as restorative justice as a viable alternative: victim-offender-community mediation within and outside prisons - a synopsis of different practices throughout the EU and, effective implementation and application of restorative justice (EFRJ, 2017 pg. 1). Unfortunately, there is no publication that expands in further details about the application of restorative justice, but Dr. Claes is encouraged to publish his findings to expand the knowledge integration of restorative 
justice in immigration detention. Seminars, such as this and other conferences, demonstrate how the application of restorative justice to an immigration context has become significant, and are indicative of the further production of knowledge and literature on this topic.

\section{Critical Application of Restorative Justice}

\section{Solving the Detention Problem}

ATD itself is already a great start to improving the immigration detention system. ATDs allow for the treatment of migrants and asylum seekers with dignity, humanity and respect (UNHCR, 2016, Bloomfield, 2016) as opposed to what is expected through the current immigration detention system. Restorative justice approaches could be used to address the issues related to detention, of which one of the outcomes may involve ATDs. ATDs will always be less harmful than detention, and including restorative justice, the approach can improve the ATD process even more. As previously discussed in the literature review, there are a number of different studies and articles that highlight the many issues that surround detention. Immigration detention impacts migrants' physical and psychological health in the long and short-term (Bloomfield, 2016). Some academics also believe that the experience of immigration detention leaves migrants to be untrusting of authorities and inhibits the integration prospects even further. This is especially true for those who are detained upon arriving, and who can potentially lose trust and faith in a system where they thought they would be safe in (Bloomfield, 2016).

As mentioned previously, the primary goal of restorative justice is to provide a framework or lens for thinking about crime and justice and, in this case, immigration detention. Restorative justice principles and programs arguably present a creative solution for addressing 
the critical issues that surround immigration detention. A restorative justice approach towards ATD has yet to be introduced to immigration detention in Canada, but there is overwhelming potential for it to flourish. This section will present empirical evidence to support how restorative justice ideologies and practices may be a feasible solution for these issues.

One of the most significant issues, as mentioned earlier, is that immigration detention systems, in their present form, do not support case resolution. There is a consistent issue of a backlog of cases within the bureaucracy of immigration detention. Long wait times not only increase anxieties and other mental health impacts on those being detained, but there is also still the issue of difficulty accessing outside social services. Restorative justice practices can be used to mediate and negotiate the access of appropriate services and get emotional reassurance and support. For example, a process for one-on-one mediation involving both migrants and the caseworkers could be introduced which can highlight and identify certain issues that they are facing, as well as humanize the process by putting a face to a name. Individuals who would mediate these sessions could be professionals such as social workers, public servants or professional mediators.

Furthermore, in an editorial written by Dr. Henrik Elonheimo from the Faculty of Law and Research Centre for Child Psychiatry at the University of Turku, it is stated that "the growth of restorative justice is also important in order to relieve the caseload of the official justice system" (Elonheimo, 2017 pg. 1). This could be beneficial for the Canadian immigration detention system as a means of efficiently reducing the caseload backlog. Cases better suited to a restorative justice approach could be identified and dealt with more efficiently, providing some relief to the system. Furthermore, studies have shown that participation in a restorative justice approach reduces the chances of participants to 'offend.' In 2011, the New Zealand Ministry of 
Justice conducted a study found that offenders had a $20 \%$ lower re-offending rate compared to those who did not receive a restorative justice conference (Bidois, 2016 pg. 600). In the immigration detention context, 're-offending' could involve offences such as choosing to flee or failing to attend appeal hearings. Studies such as these can be replicable in a Canadian immigration context, but as of yet, there has not been any study that has been conducted. Such a study would be beneficial if it can show that treating detainees with respect and dignity, addressing all of their needs (via a restorative justice approach) will result in high rate of compliance with the rules and requirements.

Another significant issue that was presented in the literature is that immigration detention is a violation of international human rights law as well as the Canadian Charter of Rights and Freedoms (1982). As previously mentioned, arbitrary detention directly violates individual legal and human rights (Canadian Charter of Rights and Freedoms, 1982). Restorative justice could be a viable solution to mend these violations, especially for those migrants who are undergoing indefinite detention. If there was to be a restorative justice program in place, group mediation could be used to more efficiently assess whether or not the individuals should be released to an ATD program or be returned to their country of origin, depending if it is safe to return. Group mediation would entail a third party mediator, either provided by community partners or a private party, who would individually meet with caseworkers, detainees and potential ATD representatives to determine if ATD can be a viable option. Considering the needs of both the migrant and the government in such a process would go a long way into addressing concerns over violations of human rights. Restorative justice would address human rights concerns that are brought up in immigration detention by allowing the voice of the migrant to be heard, and for 
the individual to participate and vocalize their needs and have their needs addressed in a sincere manner.

Certain studies have also highlighted that immigration detention is financially expensive due to the high capital costs of buildings to hold detainees with the necessary infrastructure and staff (IDC, 2018). As previously discussed, it costs Canada CA $\$ 179$ per individual per day for detention, compared to CA $\$ 12$ a day per person for alternatives (IDC, $2018 \mathrm{pg}$. 11). These alternatives to detention can be a more cost-efficient option that the Government of Canada should consider and restorative justice principles could be used, by addressing specific the needs of all parties, to efficiently identify those most suited to ATD. In a similar analysis to determine the financial feasibility of restorative justice programs, it was determined that the cost of keeping an individual detained in a UK prison could pay for 50 restorative justice conferences (Bidois, 2016). If the same were true in the Canadian context, taking this approach could be a significant point of savings for the Canadian Government as well as facilitating the process for individuals to have the opportunity to explore alternatives efficiently.

Immigration detention globally and in Canada has proven to be expensive and a violation of an individual's fundamental human right, especially with the prolonged practice of indefinite detention. These issues surrounding immigrant detention can no longer be ignored, and better and more creative solutions are needed immediately. Evidence has proven that there is the potential for restorative justice to be a creative solution to target specific issues that the Canadian Government faces in regards to immigration detention. When moving forwards, the continued research in this area will help progress a restorative justice solution into a reality 


\section{Barriers in applying Restorative justice to Immigration}

Unfortunately, there are some barriers that need to be addressed when moving forward with the application of restorative justice to immigration detention. Sullivan highlights some of these barriers, specifically for irregular immigration in the USA. The first is the use of deportation as the first line of defence against immigration offences. Arguably, detention, and not deportation, may be the first line of defence for illegal immigration in Canada but restorative justice cannot be practiced if there is no chance to remain in Canada. If the case of deportation were to be the reality for migrants, there is little that restorative justice can do to help appeal their case. There is a lack of appeal for designated foreign nationals as well as many different procedural difficulties immigrants face to defend themselves against deportation.

The second barrier is the criminalization of illegal entry as a way for government officials to avoid processing asylum claims (Sullivan, 2017). This is definitely a barrier that is placed on asylum seekers coming into Canada from the US border. There has been an increase in the use of language (in media and by some politicians) characterizing asylum claimants crossing from the U.S. as illegal immigrants (Hill, 2018, CBC News, 2018). As previously discussed, we know that these individuals are not 'illegal.' However, the public use of this terminology, calling these individuals illegal has begun to change the public discourse and the belief that they are illegal (Hill, 2018). This shift in perception can potentially impact restorative justice initiatives because the community that shapes the political decisions of the state will impact the reception of these individuals. If the public considers that these individuals are illegal, then, presumably, there will be a greater possibility that the Federal Government will react by increasing security and limit the number of accepted applicants. What makes a restorative justice approach to alternatives to detention be transformative and powerful is the participation of all parties willing and wanting to 
reconcile. However, restorative justice may not be constructive if there isn't a government body that supports the program.

Sullivan also highlights that unauthorized immigrants who are failed asylum seekers present significant obstacles as there is the possibility that these individuals obtained false documentation, making them guilty of committing identity fraud (Sullivan, 2017). Although there is supposedly some leniency when individuals are claiming asylum with false documents, the majority of these individuals are detained as a result. Restorative justice programs could be powerful in this case as the reality is that, without documentation, it can be difficult to prove that there is no security threat leading to harsh treatment for these individuals. These barriers present concerns for applying restorative justice to issues of immigration because what is seen as violations and criminal acts against the state is immediately seen as a justification for harsh action and for providing no alternatives. Restorative justice can be a potential solution if the Government can acknowledge that, in many cases, the violations and supposedly criminal acts were committed out of desperation and that these migrants are often victims as well. In these cases, there would be potential for ATD programs and restorative justice to impact Canadian society by addressing the harms that immigration detention has caused and providing a pathway to integrate and become an asset to the Canadian immigration system.

\section{Areas for Further Research and Development}

Many scholars argue there is no one best solution when moving forward with changing the immigration detention system. That being said, the push for change and for restorative justice to be at the heart of that change comes from the continual advocacy for ATDs. Stakeholders, 
advocates against immigration detention and the general public need to lobby all levels of government and hold them accountable to build community-based non-detention models while maintaining human rights standards (Flynn, 2017). Building ATD programs is an important first step for building the Canadian government's confidence in community models as the norm (Flynn, 2017). Furthermore, there needs to be a call for more expanded research on restorative justice initiatives in immigration in general. Both restorative justice and immigration detention research has flourished independently, with very little to no overlap of both concepts. The production of more research and analysis in this area might prove to be useful for advancing areas of immigration research. Finally, we need to immediately look to restorative justice-based ATD to look at solutions for indefinite detention, detention of minors and access to health care. The Canadian immigration system cannot continue the way it is without immediately addressing these concerns.

CBSA is beginning to work with community stakeholders such as the Red Cross in order monitor Canadian Immigration detention centres and to ensure that these institutions maintain high standards of exceptional quality of health (Sevunts, 2017). However, this partnership, although a good step in the right direction, does not apply to alternatives to detention. Toronto based immigration lawyer Barbara Jackman remarked in a CBC article, that the partnership between the Canadian Red Cross and CBSA as 'useless' as the Red Cross has been privately monitoring Canadian immigration detention since 1999, but has never once published or pressured CBSA to make changes (Sevunts, 2017). CBSA needs to work with community partners like the Red Cross to create a well-rounded ATD program, following up on its framework promises. In particular, partnerships with community organizations can positively impact CBSA ATD goals including the development of a Community Case Management 
Supervision program and the expanded use of technology such as electronic supervision tools and a nationally available voice reporting system (CBSA, 2018). Recently, as of 2017, CBSA announced a new partnership with the John Howard Society of Canada and the Salvation Army to ensure new ATD programs and community monitoring would be implemented by April 2018 (Scotti, 2017). As of July 2018, CBSA will announce new alternatives to immigration detention, with the hope of providing more risk-based nationally consistent programming (Harris, 20018). Once ATD programs can be piloted, restorative justice can work towards building a better detention system that focuses on alternatives. However, the implementation of ATDs might be hindered without more transparency on immigration detention statistics.

Transparency of detention statistics is a significant area that requires more attention. Not only was this a major obstacle for this research study, but it has also recently become an issue for the Canadian government as the discourse of irregular border crossings and increased detention have become a favourite media topic. The lack of transparency has organizations, such as the Global Detention Project and other research groups that promote the human rights of migrants, particularly concerned about the statistics that surround immigrant children and health care (Keung, 2018). This lack of transparency is, argued by crucial stakeholders, perpetuating the culture of secrecy surrounding Canadian immigration detention systems (Keung, 2018), primarily as one of the key pillars in the NIDF is transparency. Further research on areas of restorative justice and immigration detention is possible and can be really insightful. However, in order for this research to progress further beyond just an idea, restorative justice practitioners need to know the types of demographics of migrants who are being detained, how many are turned away and the how many of these individuals have had access to proper's services. The lack of transparency is not only limiting for restorative justice Practitioners, but it is difficult for 
other institutions to get a sense of immigration detention statistics, creating more uncertainty over the validity of the statistics.

A predominant suggestion that could be of great significance to the Canadian government is to re-work the NIDF, so that supports a restorative justice viewpoint. The fundamentals of the NIDF would remain but expressed through a restorative justice lens to integrate some of its ideologies into the framework. The essence of the NIDF would remain, but the tone of the messaging would be slightly altered. Realistically this wouldn't be too much work for the Canadian government, as a lot of the framework can potentially support a restorative justice approach. Re-working the NIDF with a restorative justice lens can help normalize this concept for the Canadian government as well as the people of Canada to facilitate the use of restorative justice principles and approaches.

Specific research and studies that would be beneficial relate to assessing the value of restorative justice approaches to specific problems in immigration detention. Today, some aspects of restorative justice do exist within the immigration system, although they might not be recognized as such or implemented in a cohesive, coordinated and consistent manner. Research that studies the impact of these approaches, when they are used, would be useful to assess the value in pursuing a cohesive restorative justice approach to immigration. For instance, a study of the rate of compliance ('re-offending') of those on ATD in Canada would be valuable. Human rights experts could also study the impact of restorative justice practices on addressing violations according to international law. Another study could assess the efficiency of moving cases forward and reducing the overall number of detainees if restorative justice methods were in place. Other studies for immigration and restorative justice scholars could involve case resolution rate for those following restorative justice practices, success in a settlement when 
restorative justice is applied, impact on mental health and the assessment of human rights violations when restorative justice is followed. The pursuit of studies in this area will hopefully provide momentum to create advance the research conducted in this area and potentially launch pilot restorative justice projects.

\section{Conclusion}

Immigration detention is increasingly becoming a more significant issue that the Canadian government can no longer ignore. Throughout the course of this study, we have intensely reviewed Canada's NIDF initiative, in particular, the ATD section of the framework. Within ATD there is definitely the capacity for restorative justice to flourish and be worked into the framework. restorative justice is defined as "a process to involve, to the extent possible, those who have a stake in a specific offence and to collectively identify and address harms, needs, and obligations, in order to heal and put things as rights as possible.” (Zehr, 2011,pg. 15). Similarly, ATD works to provide a variety of different options for a nation-state to avoid detention (IDC, 2018). A restorative justice approach can be one option for a nation-state to, not only address issues within detention but hopefully also avoid methods of detention. The IDC defines alternatives to immigration detention as "Any law, policy or practice by which persons are not detained for reasons relating to their migration status" (IDC-There is an alternative, 2018 pg. 1).

Research surrounding the topic of restorative justice and immigration is significant for advancing immigration detention research on areas of ATD by adding to the knowledge base for addressing detention-related issues, such as cost-effectiveness, the execution of a national execution detention framework and the creation of alternatives to detention programs. The 
application of restorative justice is not intended to further criminalize a demographic of individuals who are not criminals, but to proved reconciliation with those who are un-justly incarcerated. There is a gap in knowledge on the subject of restorative justice and immigration. This gap is significant as the knowledge of using restorative justice within immigrant communities has the potential to provide new understanding and approaches to issues that migrants may be facing in Canada today.

When moving forward, there is no one best solution to change the immigration detention system. Restorative justice should arguably be at the heart of that change comes from the continual advocacy for ATDs. The persistent lobbying of the Canadian government is imperative to hold the government accountable to build community-based non-detention models while maintaining human rights standards (Flynn, 2017). Currently, the classification of DFN is not being used by the present Canadian government. However, if this were to change, this would mean a large group of people who are being incarcerated by the Canadian government contrary to article 31 of the 1951 convention relating to the status of refugees (UNHCR, 2011). To prevent this from occurring, the continual advocation for ATDs in Canada is needed.

Additionally, there needs to be a call for more expanded research on restorative justice initiatives in immigration. Both restorative justice and immigration detention research has flourished independently, with very little to no overlap of both concepts. The production of more research and analysis in this area might prove to be useful for advancing areas of immigration research, as well as progress ATD in Canada in the whole. Transparency of detention statistics is a significant area that requires more attention. Not only was this a major obstacle for this research study, but it has also recently become an issue for the Canadian government as the discourse of irregular border crossings and increased detention have become a favourite media 
topic. The lack of transparency has organizations such as the Global Detention Project and other research groups that promote the human rights of migrants are concerned in particular about the statistics that surround immigrant children and health care (Keung, 2018).

The predominant suggestion that could be of great significance to the Canadian government is to re-work the NIDF, so that supports a restorative justice lens to integrate some of its ideologies into the framework. Realistically this wouldn't be too much work for the Canadian government to do, as a lot of the framework can potentially support a restorative justice approach. The significance of re-working the NIDF with a restorative justice lens is that it can help normalize a new concept for the Canadian government as well as the people of Canada so that restorative justice principles and approaches can be possible.

Over the course of this study, I have learned that there is tremendous potential for restorative justice to flourish within immigration initiatives. Further research and potential pilot projects can help advance and combine both areas of study. In particular, there significance of restorative justice and immigration detention should be a key priority for CBSA to consider when moving forward with its NIDF and the further development of ATD. 


\section{Bibliography}

Bloomfield, A. (2016). Alternatives to Detention at a Crossroads: Humanisation or Criminalisation? Refugee Survey Quarterly,35(1), 29-46. doi:10.1093/rsq/hdv018

C-31, Publication Number 41-1-C31E Library of Parliament (2012) (enacted).

Canadian Broadcasting Company News. (2018, June 18). What's real, and what's not, about the U.S. border crisis. Retrieved from https://www.cbc.ca/news/world/us-immigration-factcheck-1.4711267

Canadian Border Service Agency. (2018, March 28). Arrests, Detentions and Removals (Canada, Canada Border Service Agency). Retrieved from https://www.cbsa-asfc.gc.ca/securitysecurite/detent/stat-2012-2017-eng.html

Canadian Border Service Agency. (2018, March 16). National Immigration Detention Framework (Canada, Canada Border Service Agency). Retrieved from https://www.cbsaasfc.gc.ca/security-securite/detent/nidf-cndi-eng.html

Canadian Border Service Agency. (2018) Quarterly Detention Statistics - 2017-2018 [Table 1.1] National Immigration Detention Framework. Retrieved from https://www.cbsaasfc.gc.ca/security-securite/detent/qstat-2017-2018-eng.html

Canadian Council for Refugees. (2015, January). Alternatives to detention: CCR comments regarding the Toronto Bail Program. Retrieved from http://ccrweb.ca/en/alternativesdetention-comments-toronto-bail-program

Charter of Rights and Freedoms, s 9, Part 1 of the Constitution Act, 1982, being Schedule B to the Canada Act 1982 (UK), 1982, c 11

Department of Justice (DOJ). (2017, November 27). restorative justice. (Canada, Department of Justice) Retrieved from http://www.justice.gc.ca/eng/cj-jp/rj-jr/index.html

Draisma, M. (2016, May 16). The federal government is reviewing immigration detention process after stringing of deaths. CBC News. Retrieved from http://www.cbc.ca/news/canada/toronto/public-safety-immigration-detention-1.3584700

European Forum for restorative justice (EFRJ). (2017, February). Seminar on alternatives to detention in Romania. Retrieved from http://www.euforumrj.org/events/seminaralternatives-detention/

Flynn, M. J., \& Flynn, M. B. (Eds.). (2017). Challenging immigration detention : academics, activists and policy-makers. Retrieved from https://ebookcentral-proquestcom.ezproxy.lib.ryerson.ca

Flynn, M. J., \& Flynn, M. J. (2017). Conclusion: The many sides to challenging immigration detention. In M. B. Flynn (Ed.), Challenging Immigration Detention Academics, Activist and Policy-makers(1st ed., pp. 293-304). Edward Elgar Publishing, Incorporated. 
Fujimoto, M. (2017) restorative justice Practices within Immigrant Communities. Unpublished Manuscript

Global Detention Project. (2018, June). Immigration Detention in Canada: Important Reforms, Ongoing Concerns (Publication). Retrieved file://C:/Users/FUJIMOMA/Downloads/GDPImmigration-Detention-Canada-2018.pdf

Harris, K. (2017, May 16). Why does Canada indefinitely jail immigration detainees? [CBC News]. Retrieved April 11, 2018, from http://www.cbc.ca/news/politics/canadaimmigration-detention-1.4115511

Harris, K. (2019, July). Border agency to announce new alternatives to immigration detention [CBC News]. Retrieved from https://www.cbc.ca/news/politics/cbsa-border-agencyimmigration-detention-1.4752278

Hussan, S. (2014). Indefinite, arbitrary and unfair. End Immigration Detention Network.

Immigration and Refugee Protection Act S.C. 2001, c. 27 (Can.).

Immigration Refugee Board of Canada. (2018, June 25). Detention Review Process. (Canada, IRB) Retrieved from https://irb-cisr.gc.ca/en/legal-

policy/procedures/Pages/ProcessRevMot.aspx

International Detention Coalition. (2015, June). There are Alternatives (Issue brief). Retrieved https://idcoalition.org/wp-content/uploads/2016/01/There-Are-Alternatives-2015.pdf

International Organization for Migration (IOM). (2016, March 16). Key Migration Terms. Retrieved from https://www.iom.int/key-migration-terms

Johnstone, G., \& W., V. N. (2011). Handbook of restorative justice. London: Routledge.

Kennedy, B. (2018, February). Immigration Detainee Ebrahim Toure marks five years without freedom: 'What's going on with me is not right.' Toronto Star. Retrieved from https://www.thestar.com/news/canada/2018/02/25/immigration-detainee-ebrahim-touremarks-five-years-without-freedom-whats-going-on-with-me-is-not-right.html

Keung, N. (2018). Canada slammed for 'culture of secrecy' over immigration detention.

Mainwaring, C., \& Cook, M. L. (2018). Immigration detention: An Anglo model. Migration Studies. doi:10.1093/migration/mny015

Marouf, F. (2017). Alternatives to Immigration Detention. Cardozo Law Review,38, 2141-2191.

McCold, P., \& Wachtel, T. (2011). restorative justice Theory Validation. In E. G. Weitekamp \& H. Kerner (Eds.), restorative justice: Theoretical Foundations. New York, NY: Routledge 
McGillivary, K. (2017, May 1). Immigration detainee freed after being held in Canada for 7 years due to 'legal limbo.' $C B C$ News. Retrieved from http://www.cbc.ca/news/canada/toronto/programs/metromorning/kashif-ali-released$\underline{1.4093176}$

Miller, J. M., Gibson, C. L., \& Byrd, J. (2008). Getting beyond the Liberal Feel-Good: Toward an Accountability-based Theoretical Research program for restorative justice. In $\mathrm{H}$. Ventura Miller (Ed.), restorative justice: From Theory to Practice (Vol. 11, Sociology of Crime and Deviance, pp. 261-278). Bingley, UK: Emerald Publishing Limited.

Molnar, P., \& Silverman, S. J. (2017, November). Migrants are dying in Canadian detention centres. The government needs to act. Macleans. Retrieved from https://www.macleans.ca/opinion/migrants-are-dying-in-canadian-detention-centres-thegovernment-needs-to-act/

Nakache, D. (2011). The Human and Financial Cost of detention of asylum seekers in Canada. UNHCR, 5-100.

National Centre for Truth and Reconciliation (NCTR). (2015). About | NCTR. Retrieved from http://nctr.ca/about-new.php

Perkel, C. (2017, May 5). Indefinite immigration detention in Canada under fire in Federal Court. The Canadian Press. Retrieved from https://search-proquestcom.ezproxy.lib.ryerson.ca/docview/1899615829?pq-origsite=summon

Pratt, A. (2005). Securing borders. UBC Press.

Quigley, C. (2013). AN ARGUMENT AGAINST IMMIGRATION DETENTION OF ASYLUM SEEKERS IN CANADA (Unpublished master's thesis). The University of Toronto.

Sampson, R., \& Mitchell, G. (2013). Global trends in Immigration detention and alternatives to detention practical political and symbolic rationales. Human Rights Documents Online, l(3), 97-121. doi:10.1163/2210-7975_hrd-9934-3006

Scotti, M. (2017, December). CBSA to use GPS, check-ins to track immigration detainees instead of imprisoning them [Global News]. Retrieved from https://globalnews.ca/news/3926771/cbsa-to-use-gps-check-ins-to-track-immigrationdetainees-instead-of-imprisoning-them/

Sevunts, L. (2017, July). Red Cross to monitor Canada's immigration detention centres [CBC news]. Retrieved from https://www.cbc.ca/news/politics/red-cross-cbsa-immigrationdetention-1.4226095

Shields, J., \& Evans, B. (2012). Building a Policy-Oriented Research Partnership for Knowledge Mobilization and Knowledge Transfer: The Case of the Canadian Metropolis Project. Administrative Sciences, 2(4), 250-272. doi:10.3390/admsci2040250 
Silverman, S. J. (2014). In the Wake of Irregular Arrivals: Changes to the Canadian Immigration Detention System. Refuge, 30(2), 27-34. Retrieved from https://refuge.journals.yorku.ca/index.php/refuge/article/viewFile/39616/35895.

Sullivan, M. J. (2017). A restorative justice approach to legalizing unauthorized immigrants. restorative justice,5(1), 70-92. doi:10.1080/20504721.2017.1294793

Thwaites, R. (2014). Canada. In The Liberty of Non-Citizens : Indefinite Detention in Commonwealth Countries(Vol. 1, pp. 225-283). Bloomsbury Publishing PLC.

United Nations High Commissioner for Refugees. (2011). Global Roundtable on Alternatives to Detention of Asylum-Seekers, Refugees, Migrants and Stateless Persons: Geneva, Switzerland, 11-12 May 2011. International Journal of Refugee Law,23(4), 876-883. doi:10.1093/ijrl/eer029

United Nations High Commissioner for Refugees. (2016). Alternatives to Detention. International Journal of Refugee Law,28(1), 148-155. doi:10.1093/ijrl/eew005

United Nations High Commissioner for Refugees (UNHCR). (2011), The 1951 Convention relating to the Status of Refugees and its 1967 Protocol, available at http://www.refworld.org/docid/4ec4a7f02.html [accessed 6 September 2018]

United Nations High Commissioner for Refugees (2010, October 13). Toolkit on Diversion and Alternatives to Detention. Retrieved from https://www.unicef.org/tdad/index_56513.html

United Nations Office on Drugs and Crime (UNODC). (2007). Handbook on restorative justice programmes (Criminal Justice Handbook series). New York: United Nations.

United Nations Office on Drugs and Crime (UNODC). (2007). Handbook of Basic Principles and Promising Practices on Alternatives to Imprisonment (Criminal Justice Handbook series). New York: United Nations.

Van Ness, D. W. (2011). The shape of things to come: a framework for thinking about a restorative justice system. In E. G. Weitekamp \& H. Kerner (Eds.), restorative justice: Theoretical Foundations(pp. 1-31). New York, NY: Routledge.

Van, Z. S. (2007). Handbook of basic principles and promising practices on Alternatives to imprisonment. (Criminal Justice Handbook Series) New York: United Nations. Retrieved from https://www.unodc.org/pdf/criminal_justice/Handbook_of_Basic_Principles_and_Promisin g_Practices_on_Alternatives_to_Imprisonment.pdf.

Zehr, H. (2015). Restorative Principles. In The Little Book of restorative justice : Revised and Updated(2nd ed., Justice and Peacebuilding, pp. 18-31). Brattleboro, VT: Good books 


\title{
Glossary
}

\author{
$\mathrm{ATD}=$ Alternatives to Detention \\ CBSA $=$ Canadian Border Services Agency \\ $\mathrm{CCR}=$ Canadian Council for Refugees \\ DFN $=$ Designated Foreign National \\ GDP $=$ Global Detention Project \\ IDC $=$ International Detention Coalition \\ $\mathrm{IHC}=$ Immigration Holding Centre \\ IRCC $=$ Immigration, Refugees and Citizenship Canada \\ IRB = Immigration and Refugee Board \\ IRPA = Immigration and Refugee and Protection Act \\ IRPR = Immigration Refugee Protection Regulations \\ $\mathrm{NGO}=$ Non Governmental Organization \\ $\mathrm{NIDF}=$ National Immigration Detention Framework \\ $\mathrm{TBP}=$ Toronto Bail Program \\ UNHCR $=$ United Nations High Commissioner for Refugees \\ UNICEF $=$ United Nations International Children's Emergency Fund \\ UNODC $=$ United Nations Office of Drugs and Crime
}

